\title{
Monopoly in the Marketplace of Ideas
}

Economics and Freedom of Expression: Media Structure and the First Amendment. By Bruce M. Owen. Cambridge, Mass.: Ballinger Publishing Co., 1975. Pp. xxi, 202. \$15.00.

\section{Reviewed by Richard A. Posner ${ }^{\dagger}$}

Bruce Owen, an economist at Stanford University, has written a useful but somewhat disappointing book $^{1}$ on an interesting subject: the effect of the structure and regulation of the communications media on diversity of expression. Stripped of its introduction and conclusion, two appendices, a long bibliography, and a "very cursory"2 chapter on magazines and motion pictures, ${ }^{3}$ the book is seen to consist of two essays, one on newspapers and the other on radio and television.

The newspaper essay (Chapter Two) is largely descriptive. The history of newspaper publication in this country is reviewed, yielding the unsurprising conclusion that the number of daily newspapers has declined sharply over time due to technological change and the competition of other media.4 Owen shows, persuasively I think, that cost and demand conditions severely limit the possibilities of competition within local newspaper markets. ${ }^{5}$ The chapter is interesting and wellwritten.

The radio-television essay (Chapter Three) is devoted largely to a description of the history and present pattern of regulation of electronic media by the Federal Communications Commission (FCG). The well-known perversities of that regulation are discussed, with appropriate indignation. ${ }^{\circ}$ Both Chapters Two and Three also describe, briefly and on the whole noncommittally, antitrust policy toward the communications industries. ${ }^{7}$

$\dagger$ Professor of Law, University of Chicago.

1. B. OWen, Economics and Freedom of Expression: Media Structure and the First AMENDMENT (1975) [hereinafter cited by page number only].
2. P. 169.
3. Pp. 169-81.
4. Pp. 48.52.
5. Pp. 50-52.
6. E.g., pp. 102-16.
7. Pp. 52-55, 122, 139-40. 
Save for some previously unpublished data on newspaper costs (compiled by Owen's colleague at Stanford, James Rosse), ${ }^{\mathrm{s}} \mathrm{I}$ found no original research in the book. Nor, I am bound to say, is the book rich in original thinking. Chapter Two is, as I have said, mainly descriptive, and Chapter Three echoes the criticisms of governmental regulation of the broadcast media made either by Ronald Coase in his pathbreaking 1959 article on the FCG ${ }^{9}$ or by others later. ${ }^{10}$ The major points are:

(1) The Supreme Court has countenanced much greater governmental regulation of the electronic media than of the print media on the ground that radio and television use the electromagnetic spectrum, a "limited" resource. In fact, the print media utilize equally scarce resources ${ }^{11}$-otherwise there would be more newspapers than there are. Furthermore, the scarcity of spectrum space is largely an artifact of governmental regulation. ${ }^{12}$

(2) In any event, spectrum scarcity has been overcome by the development of cable television, with its practically unlimited channel capacity. The realization of cable television's potential has been thwarted, however, by governmental regulation-in particular by the FCC's limitations on pay television, which deny viewing minorities greater access to television than that provided by the existing broadcast system and thereby limit diversity of expression. ${ }^{13}$

Lack of originality need not condemn a book; a book that summarized the scattered economic literature on the communications media would serve a useful purpose. Owen's book does this, but it is too diffuse, polemical, and structurally unbalanced to fill the bill completely. The introductory chapter confesses the author's inability to deal "with the issues in this chapter in a 'linear' fashion."14 The newspaper chapter is too detailed, the radio-television chapter too sketchy, and the book as a whole too freighted with tables, appendices,

8. P. 35 .

9. Coase, The Federal Communications Commission, 2 J.L. \& EcoN. 1 (1959).

10. See, e.g., Posner, The Appropriate Scope of Regulation in the Cable Television Industry, 3 BELL J. Econ. \& MGMT. ScI. 98 (1972); Johnson, The Future of Cable Television: Some Problems of Federal Regulation (RAND Corp. Jan. 1970).

11. Pp. 106-07; R. POSNer, Economic ANalysis of LAw 313 (1972).

12. Pp. 106-07; R. Posner, supra note 11, at 313; Coase, supra note 9, at 20-21, 27-28.

13. Pp. 114-16, 136-37; Posner, supra note 10, at 102-06; Posner, The Probable Effects of Pay Cable Television on Culture and the Arts, in THE ElEctronic Box OfFICE: Humanities and ARTS on the Cable 79, 89-90 (R. Adler \& W. Baer eds. 1974). The appendix to Chapter Three, written by Owen in collaboration with Michael Spence, constitutes a more rigorous analysis of the likely effects of pay television than previously attempted. Its main conclusions, however, accord with those of the informal analysis of the carlier literature. Compare pp. 164-65 with Posner, supra note 10, at 102-06.

14. P. 1. 
and other distractions to satisfy the reader seeking an introduction and summary.

I am bothered by the author's breathless style and by the number of unexplained and unsupported assertions in the book. The following are some examples:

And surely the most powerful and subtle vehicles for attitude change and persuasion, as well as reinforcement, are dramatic and literary works. ${ }^{15}$

On the other side, it is probably a lot harder today to reach everyone in a local community with a message than it was 100 or 150 years ago, or at least there are fewer ways of doing it. ${ }^{16}$

The notion that television is uniquely powerful and influential, and hence requires government regulation for "McLuhanesque" reasons, is almost certainly the result of the unnatural degree of economic concentration and advertiser dominance that flows from present regulatory policy. ${ }^{17}$

We do not want a fair and balanced press-we want a system of expression which is robust and partisan and impassioned. ${ }^{18}$

A more serious shortcoming of the book is that, as the last passage I quoted may suggest, Owen lacks a clear conception of what it is he wants from the media. It is possible to appraise the performance of the communications media from the standpoint of economics by using the criterion of efficiency. But, like many economists, Owen apparently prefers to approach the problem from a different, less confining standpoint. His touchstone is not efficiency but the First Amendment-and not its letter ("Congress shall make no law ... abridging the freedom of speech, or of the press") but its spirit, which in Owen's view implies "a positive obligation to intervene in various carefully defined ways when freedom of expression is threatened by private agglomerations of power."19 "Freedom of expression," however, is nowhere adequately defined. ${ }^{20}$ It is in Owen's hands a slogan used to carry his argument over difficult points.

In his fervor for freedom, Owen assumes the mantle of the "libertarian." 21 That is a fair description of his attitude toward current

15. P. 11.

16. P. 52 .

17. P. 120 .

18. P. 188.

19. P. 2.

20. Owen's most explicit attempt at definition is: "Freedom of expression must . . . mean something like equal freedom of all speakers .... I believe this notion of freedom is approximated by an economically competitive market for ideas." P. 4.

21. P. 2. 
governmental regulation of the media. Yet he seems also to favor, more tentatively in the body than in the conclusion of the work, ${ }^{22}$ such highly intrusive forms of media regulation as making newspaper printing plants common carriers, ${ }^{23}$ breaking up the networks or limiting the amount of programming they may originate, ${ }^{24}$ and stripping cable television operators of all program control. ${ }^{25}$ Whether the total impact of Owen's various proposals can fairly be described as "libertarian" may be doubted.

My sharpest disagreement with Owen concerns precisely the basis of his proposals, tentative as they may be, for subjecting the media to novel forms of governmental control. Owen conceives of media firms as "gatekeepers" that control the flow of news and opinion and screen out ideas inimical to their economic interests or otherwise uncongenial to them. ${ }^{26}$ Given this gatekeeper function, Owen argues, concentration in the media industries entails a reduction, potentially to dangerously low levels, in the diversity of views disseminated to the public. ${ }^{27}$

This argument, however, seems to be based on a confusion of the effects of monopoly on price and on product variety. No doubt a media monopolist could charge a higher price than a competitive firm, but it does not follow that he would offer a product mix different from or inferior to that which a competitive industry would offer. Owen relegates this important question to a confusing, coauthored appendix to Chapter Three, which compares competitive and monopolistic equilibria under two broadcasting systems-pay television and advertiser-supported television. Owen contends that under either system a broadcast monopolist would probably supply fewer programs than competitive firms, ${ }^{28}$ but he acknowledges that, where programs are highly substitutable and channels are limited, the monopolist might supply a more diverse set of programs. ${ }^{29}$ It would

22. Compare, e.g., p. 58 with p. 185.

23. Pp. 58-59.

24. Pp. $122,185$.

25. Pp. 136, 185.

26. Pp. $12-13$.

27. Pp. 26-28, 186-87.

28. Pp. 152, 157 .

29. According to Owen, at p. 159:

With very close substitutes, the tendency of monopoly to restrict programs becomes an advantage. ...

Monopoly has another potential advantage. If the number of channels is limited, competitive advertiser support may use up scarce channels with close substitutes. Monopoly may limit the number of close substitutes, and use the remaining channels for programs that are less [perfect] substitutes. Such programs may be less profitable individually but do not cut into the audiences generated by the other programs as much. 
seem, therefore, that Owen, who is concerned more with the variety than with the volume of programming, would be inclined to temper his opposition to a monopolistic organization of the media, at least if channels continue to be limited by the FCC. But he does not. ${ }^{30}$

It appears that Owen's principal objection to monopoly is not that a profit-maximizing monopolist might produce a different (and from a First Amendment standpoint inferior) product mix, but that a media monopolist might not actually maximize profits; rather, he might fail or refuse to disseminate ideas and opinions for which there is a public demand. ${ }^{31}$ However, the monopolist who thus indulged his personal tastes with respect to the news content or editorial policies of his newspaper or television station would incur a financial cost in reduced demand for his product.

Owen rejects this point by arguing that the penalty to the monopolist for indulging his personal tastes in expression is less than it would be for a competitive firm: the monopolist reduces his profits; the competitive firm jeopardizes its survival. The situation is more complex. The monopolist who fails to maximize his profits becomes an attractive target for a takeover bid by an individual or firm committed to profit maximization..$^{32}$ And it is false that a competitive firm which incurs an unnecessary cost or reduces the value of its product is thereby doomed; that depends both on the shape of the firm's marginal cost curve and on the ownership of any specialized resources used in the production of the firm's output. ${ }^{33}$ More im-

30. Owen states that "there is a school of thought" suggesting "that from the First Amendment standpoint, monopoly is not necessarily a factor leading to a decline in diversity of sources of opinion. We must reject this." P. 4.

31. Id.

32. Owen asserts that the takeover threat to non-profit-maximizing media monopolists is slight because in the newspaper industry "family ownership is still very common" and in the broadcasting industry "all controlling stock purchases must receive FCC approval." P. 5. Whether family ownership hinders or facilitates takeovers is an empirical question on which Owen provides no evidence. Family firms are mainly small, and small firms are probably easier to take over than large ones. Thus, it is not intuitive that newspaper publishers are, on balance, harder to take over than other firms. As for broadcasting takeovers, Owen cites no evidence, and $I$ know of none, that the requisite FCC approval has proven to be a significant obstacle to controlling stock purchases.

33. If a firm can reduce its marginal cost by reducing its output (i.e., if it faces an upward-sloping marginal-cost curve), then it can adjust to a fall in price (due to a fall in the quality of its product) or a rise in its costs by reducing its output. So long as this reduction leaves it producing at a point where price equals or exceeds average cost, the firm can remain in business even in a perfectly competitive market.

A firm using specialized resources that cannot or will not be shifted elsewhere by their owners can reduce output and still produce at a point on an upward-sloping marginal cost curve above average cost. If, on the one hand, the resource owners do not own the firm, they presumably would prefer to relocate the resources if the firm fails to maximize the value of the resources and hence the rents to the owners. But whether the owners can do this depends on whether their contracts with the firm permit them 
portantly, quite apart from these technical flaws, Owen provides neither evidence nor reason to support his apparent belief that media entrepreneurs commonly sacrifice profits to their desire to influence public opinion.

Furthermore, Owen's premise that monopoly power is widespread in the communications industries may be doubted. Newspapers face vigorous competition from television and other sources. All signs point to vigorous competition among the television networks, at least in programming. Indeed, economic theory suggests that oligopolistic industries are apt to compete more vigorously in nonprice dimensions of service than unconcentrated industries, in effect substituting nonprice for price competition. ${ }^{34}$ And the casual evidence-all we haveis that the private economic interests of the media owners do not shape their editorial stance or news. selection: the policies of the New York Times, Washington Post, CBS, and other "powerful" media outlets appear to be completely independent of and largely antithetical to the private economic interests of the wealthy individuals who own (or manage the business side: of) these enterprises. Owen ignores these points.

What I have said hardly constitutes a rigorous demonstration that media concentration poses no threat to diversity of expression. Elsewhere I have indicated some areas of concern. ${ }^{35}$ But Owen's argument against concentration, far from being rigorous, is; as he presents it, barren of theoretical or empirical support. Owen embraces it as an article of faith.

to do so and on whether the resources would really be more valuable in the hands of other managers. If, on the other hand, the resources are owned by the same people who own the firm, then the firm can subordinate profit maximization to the pursuit of other goals to the extent of the rents that the specialized resources generate.

34. For one version of the argument, see R. POSNER, ANrirrust Law: AN Economic Perspective 11-12 (1976).

35. Posner, supra note 10 , at 106-10. 